\title{
A Pilot Project of Tuberculosis Case-Finding and Treatment in a Seoul Industrial Population
}

\author{
Thomas Moore
}

U.S. Peace Corps Volunteer

Jeanne A. Griffith, M. D., M.P.H.

Public Health Advisor U.S. Peace Corps/Korea

\section{一國文抄錄一}

\section{서울市內 一工業地區에서의 結核發見 및 治療事業에 對한 小規模豫備調查}

\author{
토마스 무어, 지인 그리피스
}

\section{美國平和奉仕團}

工業化가 進行됨에 따라서 이에 從事하는 人員들이 增加하고 거기에 따라 이들을 爲한 保健事業의 必

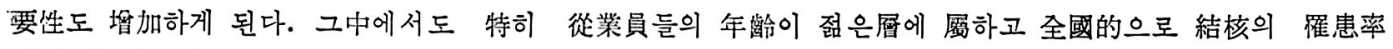
이 높기 때문에 먼저 結核管理부터 始作하는 것이 妥當하고 重要할 것으로 믿어져서 우선 小規模의 豫備 調查를 施行하였다.

清溪市場內에 있는 約 600 個의 衣類製造工場의 從業員을 對象으로 하였는데 그 數는 約 10,000 名에 達 하며 그中 $80 \%$ 는 25 歲未滿이고 男女比는 $1: 4$ 이었다. 1974年 10 月부터 12 月까지사이에 8,242 名을 調查 對象으로 하였으나 그中 4,284 名(約 $50 \%$ ) 만이 檢查에 應하였고 이中 176 名(4.1\%)이 疑似結核으로 나타 났다. 이들 疑似結核患者에 對해서 여러번 通知하고 個別訪問까지 하였으나 約 $40 \%$ 만이 面接에 應하였고 $25 \%$ 만이 追求調査에 應하였다. 그리고 治療에 應한 患者도 極少數에 不過하였다.

이 調䍒結果 몇가지 問題點이 浮刻되었다. 즉 從業員들을 篇한 診療所에 對한 反應이 上述한바와 같이 低調한 것인데 그 理由로는 從業員들의 移動이 많은것도 要因이 되었고 患者들이 指示에 順應하지 않는것 도 患者登錄이 적은 原因이 되었다. 또 한가지 要因은 結核으로 밝혀진後의 失職에 對한 敖虑도 包含되 넜을 것이다. 本調査에 依해서 結核管理施設이 必要한 것이 밝혀지기는 하였으나 効果的인 運營을 施行하 기 雹해서는 철저한 保健教育이 必要하며 자주 移動하는 患者들에 對해서 계속 追求調查 및 治療를 할수 있도록 소國의 모든 保健施設 相互間에 連絡할수 있는 方途를 講求해야 할 것이다.

This paper describes a pilot project of tuberculosis case-finding and treatment in the garment factory complexes of the

Pursuant to current Peace Corps regulations it is necessary to state that the views expressed herein are those of the writers and are not to be considered as an official expression of the Peace Corps as an Agency of the United States Gov' t.
Chongkye market district of Seoul. The young workers in these factory districts are at high risk of disease because of their working conditions and the stresses of adolescence. Infection, as determined by the tuberculin skin test, has occurred in over $60 \%$ of Koreans by the second decade 
of life. Adolescence and the early adult years are both age periods of high risk of developing manifest tuberculosis.

Prior to this pilot program, workers with tuberculosis in the garment factories had to seek treatment at government health centers or at private clinics because of lack of services at the factory clinic. Many failed to seek or to complete treatment.

\section{The Garment Factory District}

Ten building complexes in the Chongkye market district are subdivided into factories. Each complex has a worker population ranging from 160 to 2,140 , and each factory is owned and managed by a single employer. The 600 factories employ approximately 10,000 people, $80 \%$ of whom are 25 years old or less. The ratio of female employees to male is $4: 1$. Between $50 \%$ and $60 \%$ of the employees belong to a family living outside of Seoul, so most stay with relatives or friends while they work in the city.

The wages earned per month vary according to job. Assistants are paid from $¥ 8,000$ to 15,000 ; sewing machine operators, $\# 20$, 000 to 30,000 ; assistant cutters, $¥ 40,000$ to 50,000 ; and cutters, $¥ 60,000$ to 70,000 .

A single factory may consist of an area of 500 to 1,000 square feet and employ from 15 to 20 people. Physical conditions vary from factory to factory but certain recurring problems can be noted. The working area of ten is increased by constructing a partial partition to add a second story which is advantageous for increased production but limits ventilation and necessitates the use of artificial light. Electric fans are operated only during the summer months. Such inadequate ventilation allows tubercle bacilli concentrate in the area around an infectious: patient and increases the danger of infection for nearby workers Sunlight with its natural bactericidal effect cannot penetrate effectively into the working areas.

The Chongkye Workers' Welfare Clinic under the auspices of the Korean Industrial Health Association provides health services for workers. The personnel of the clinic are responsible for diagnosis and treatment of routine complaints, first aid to the injured, and periodic screening physical examinations. A chest $\mathrm{x}$-ray (indirect film) is part of the examination. The clinic director is responsible to an advisory board which includes a representative of the Asian American Free Labor Institute (AAFLI), which is an international affiliate of the American Federation of Labor-Congress of International Organizations (AFL-CIO).

\section{Preliminary Planning}

Support for a tuberculosis case-finding and treatment project was obtained from AFFLI and the Garment Workers' Union. When the program was planned, a number of potential problems were identified. The primary concern was the patient load.

In the spring of 1974, clinic personnel had examined 8,000 workers of an adjacent market area and had identified 330 individuals $(4.1 \%)$ as tuberculosis suspects. This rate seemed indicative of what proportion might be found among the garment workers -possibly 400 of the 10,000 employees would be identified as suspects. A patient load of this size would strain clinic facilities because neither additional space or manpower was available for the clinic. The transitory living and working patterns com- 
Table 1. Results of Initial X-ray Screening (October-Decomber 1974)*

\begin{tabular}{lcccc}
\hline Market area & $\begin{array}{c}\text { No. of workers } \\
\text { employed }\end{array}$ & $\begin{array}{c}\text { No. of workers } \\
\text { examined }\end{array}$ & $\begin{array}{c}\text { No. with } \\
\text { suspicious X-ray }\end{array}$ & $\begin{array}{c}\text { \% with } \\
\text { suspicious X-ray }\end{array}$ \\
\hline Pyongwha market & 518 & 343 & 23 & 6.7 \\
Donghwa market & 2,141 & 1,097 & 27 & 2.4 \\
Tongil market & 1,414 & 624 & 35 & 5.6 \\
Ulji market & 1,425 & 784 & 21 & 2.7 \\
Younsei market & 349 & 236 & 6 & 2.5 \\
Shin-pyonghwa market & 616 & 214 & 22 & 10.3 \\
Pukwan market & 480 & 191 & 8 & 4.2 \\
Dongmun market & 889 & 568 & 22 & 3.9 \\
Seongdong Bldg. & 158 & 75 & 3 & 4.0 \\
Ulho Bldg. & 252 & 152 & 9 & 5.9 \\
\hline Totals & 8,242 & 8,284 & 176 & 4.1. \\
\hline
\end{tabular}

* Excluded are workers from business of fices and three market areas with less than $20 \%$ participation in the initial screening physical examination.

Table 2. Status of 111 Tuberculosis Suspects at Time of Followup Interview and One Month Later

\begin{tabular}{|c|c|c|c|c|}
\hline & \multicolumn{2}{|c|}{$\begin{array}{l}\text { Initial } \\
\text { interview }\end{array}$} & \multicolumn{2}{|c|}{$\begin{array}{l}\text { After } \\
\text { one month }\end{array}$} \\
\hline & No. & $\%$ & No. & $\%$ \\
\hline $\begin{array}{l}\text { Suspects still in need of } \\
\text { followup }\end{array}$ & 34 & 31 & 27 & 24 \\
\hline $\begin{array}{l}\text { Suspects with followup } \\
\text { tests, no disease }\end{array}$ & 21 & & 26 & \\
\hline $\begin{array}{l}\text { Suspects with followup, } \\
\text { treatment initiated elsewher }\end{array}$ & re 3 & & 2 & \\
\hline $\begin{array}{l}\text { Suspects with followup, } \\
\text { disease inactive }\end{array}$ & 1 & 31 & 1 & 40 \\
\hline $\begin{array}{l}\text { Suspects with followup, } \\
\text { x-ray questionable, need } \\
\text { further examination }\end{array}$ & 1 & & 2 & \\
\hline $\begin{array}{l}\text { Suspects with disease, } \\
\text { registered in clinic }\end{array}$ & 9 & & 13 & \\
\hline Discontinued employment & 32 & 39 & 30 & 36 \\
\hline Factory closed & 10 & & 10 & \\
\hline Totals & 111 & 101 & 111 & 100 \\
\hline
\end{tabular}

mon to young workers in urban industries was a second concern of the project.
Furthermore, there was no precedence for a disease-specific control program in an industrial population. The response, therefore, of the employers and employees could not be anticipated.

The clinic director and the AAFLI personnel were enthusiastic about a pilot project, however, inspite of these problems. Funding for 50 patients was authorized by the AFL-CIO for one year, and this limited the patient load until the program could be assessed.

\section{Plans for Records and Management}

Records were designed using the government system as the model. Included in the records were a registration book, a patient registration card, a patient identification card, a medicine utilization book, a daily treatment book, and a results book for sputum tests. The registration card included the individual's name, work and home addresses, age, sex, previous treatment if 
Table 3. Age, Sex, and Family Residence of Patients Registered for Treatment

\begin{tabular}{|c|c|c|c|c|c|}
\hline \multirow{2}{*}{ Age } & \multicolumn{2}{|c|}{ Seoul } & \multicolumn{2}{|c|}{ Outside of Seoul } & \multirow{2}{*}{ Totals } \\
\hline & Male & Female & Male & Female & \\
\hline $15 \mathrm{yr}$. or less & 0 & 1 & 0 & 0 & 1 \\
\hline $16-20 \mathrm{yr}$. & 0 & 2 & 1 & 3 & 6 \\
\hline $21-25 \mathrm{yr}$ & 1 & 4 & 5 & 5 & 15 \\
\hline $26-30$ yr. & 0 & 1 & 0 & 0 & 1 \\
\hline 31 and over & 1 & 2 & 0 & 0 & 3 \\
\hline Totals & 2 & 10 & 6 & 8 & 26 \\
\hline
\end{tabular}

Table 4. Method of Discovery, Classification of Disease, History of Previous Treatment

\begin{tabular}{|c|c|c|c|c|c|c|c|}
\hline & \multicolumn{3}{|c|}{ Previous treatment } & \multicolumn{3}{|c|}{ No previous treatment } & \multirow{2}{*}{ Totals } \\
\hline & minimal & $\bmod a d v$. & far adv. & minimal & $\bmod a d v$. & far adv. & \\
\hline $\mathrm{X}$-ray screening & 3 & 0 & 0 & 11 & 1 & 1 & 16 \\
\hline Selfpresenter & 4. & 2 & 0 & 2 & 2 & 0 & 10 \\
\hline Totals & 7 & 2 & 0 & 13 & 3 & 1 & 26 \\
\hline
\end{tabular}

Table 5. Treatment Results as Determined by 3-month $\mathrm{X}$-ray Followup

\begin{tabular}{|c|c|c|c|c|c|}
\hline & \multicolumn{2}{|c|}{ Previous treatment } & \multicolumn{2}{|c|}{ No previous treatment } & \multirow{2}{*}{ Totals } \\
\hline & self presenter & $\mathrm{X}$-ray screening & self presenter & $\mathrm{X}$-ray screening & \\
\hline Improved & 3 & 1 & 1 & 9 & 14 \\
\hline No change & 1 & 0 & 0 & 1 & 2 \\
\hline Worsened & 2 & 1 & 0 & 1 & 4 \\
\hline In need of $x$-ray & 0 & 1 & 1 & 0 & 2 \\
\hline Defaulted & 0 & 0 & 2 & 2 & 4 \\
\hline Totals & 6 & 3 & 4 & 13 & 26 \\
\hline
\end{tabular}

any, and the results of the initial and the followup tests. This identification card was used in anticipation of a large patient load.

The plan was that any tuberculosis suspect identified during the physical examination was to have a full-size chest $\mathrm{x}$-ray and two sputum tests. Patients registered for treatment were to be given followup $x$-rays and sputum tests at intervals of three months.
The treatment regimen consisted of the three primary tuberculosis drugs isoniazid, streptomycin, and paraminosalicylic acid. These were to be administered to all patients for three months regardless of disease status. Medication was to be reduced to two drugs after followup tests at the end of three months.

Patient progress was to be monitored by 
the clinic director, who could authorize any necessary modifications.

\section{Case-Finding}

The physical examination period for the pilot project began in October, 1974, and continued into December, 1974. The results of the examinations were sent to the factories by the third week of December, along with the recommendation that tuberculosis suspects visit the clinic for further tests. Table 1 presents, by market area, the results of 8,242 examinations that identified 176 tuberculosis suspects.

During the following month, 12 suspects were identified as patients and were registered for treatment. Since such a small number presented for followup, a second notice was sent to inform suspects of the services provided by the clinic. After a negligible response to this notice, suspects were visited on their job sites with the assistance of the Garment Workers' Union representatives. One hundred and eleven employees were interviewed during January and February, 1975. Thirty-six percent of the suspects had left their places of employment and could not be located. Table 2 shows the status of the suspects both at the time of interview and one month later.

After two written reminders and individual visits, only $40 \%$ of the patients who were interviewed and only $25 \%$ of the total of 176 suspects identified by $\mathrm{x}$-ray had proper followup. Poor response to followup efforts related in part to the transitory nature of employment in the garment district, but $24 \%$ of the 111 suspects interviewed continued to work without adequate diagnosis.
As this program was voluntary, this situation could not be readily corrected.

The large patient load that had been anticipated did not materialize. First, 50\% of the workers did not have the initial physical examinations and, although some self-presenters appeared from this group without $\mathrm{x}$-ray screening, most remained unknown. Second, many identified suspects did not visit the clinic for followup tests. Third, many suspects who did come for followup evaluation were free of disease at the time diagnostic studies were initiated.

\section{Health Education}

Since this entire health program was voluntary, the workers had to be informed of the facts about the diagnosis and treatment of tuberculosis. They needed to know that over one half of the suspects were found to be free of disease on followup. Workers needed to understand the facts about the specific symptoms of the disease since selfpresenters constituted a significant number of individuals registered for treatment. Another important fact that had to be communicated to employees was that medical care was free and was available in the factory neighborhood. The importance of the physical examination needed to be stressed since only $52 \%$ of the eligible employees in the ten factory complexes participated.

Communication techniques for health education during the pilot project included lectures and the distribution of posters. The lectures were given at the workers' evening classes at which less than $1 \%$ of the employees participated. Informal visits to the factories and the distribution of 
health education posters appeared to have a wider impact. Union representatives aided these efforts to carry out health education.

A possible alternative method in future programs could be health education at the time of the physical examinations. Large numbers of workers are gathered together at the time of the examinations and they might then be receptive to facts about health and specific information about tuberculosis.

\section{Patient Characteristics and Treatment Results}

Presented in Table 3 are the age, sex, and place of family residence of the twentysix garment factory employees who were registered as patients at the clinic between October 1974 and March 1975. The predominance of females among the patients and the youthful age of the patients reflect the total composition of the employee population. Twenty-two patients were 25 years of age or younger at the time of registration. The family residences of 14 patients were outside Seoul.

Table 4 shows that the disease status of the patients discovered by $\mathrm{x}$-ray was minimal in 14 of 16 cases. By contrast, four of the 10 self-presenters were moderately advanced.

Thirteen of the 16 patients discovered by $\mathrm{x}$-ray had had no prior treatment whereas six of the 10 self-presenters were aware of their diagnosis and had previously received treatment.

Eleven of the 26 patients had positive initial sputum tests. Six of these 11 patients were self-presenters.

Table 5 presents the progress of 20 of the 26 patients as determined by followup
Table 6. Defaulting Correlated with Length of Treatment as of June 1, 1975

\begin{tabular}{|c|c|c|c|}
\hline $\begin{array}{l}\text { No. of } \\
\text { patients }\end{array}$ & $\begin{array}{l}\text { Months on } \\
\text { treatment }\end{array}$ & $\begin{array}{l}\text { Non- } \\
\text { defaulters }\end{array}$ & Defaulters \\
\hline 2 & 7 mos. & 1 & 1 \\
\hline 2 & 611 & 1 & 1 \\
\hline 8 & $5 \prime \prime$ & 7 & 1 \\
\hline 9 & $4 \quad 1$ & 7 & 2 \\
\hline 4 & 311 & 2 & 2 \\
\hline 1 & 211 & 1 & 0 \\
\hline 26 & & 19 & 7 \\
\hline
\end{tabular}

$\mathrm{x}$-ray. Of 12 patients initiating treatment, 10 had shown improvement on x-ray " at three months. Of the 8 patients who had prior treatment, 4 had improved, one was unchanged and three had worsened.

\section{Modification in Treatment}

Ethambutol was prescribed for 12 patients considered to have shown no improvement or only minimal improvement following three months of primary drug treatment. As of June 1, 1975 the overall response to ethambutol seemed favorable but no definitive followup had yet been carried out.

\section{Defaulting}

Each patient was counselled about the importance of his maintaining treatment and the possible side effects of the drugs. Table 6 presents the pattern of defaulting as correlated with duration of treatment. Of the seven defaulters. two decided not to have treatment at the factory clinic, one left work to convalesce at home, two changed their place of employment, a sixth 
patient left Seoul to visit relatives and did not return for treatment, and the seventh could not be contacted. Six of the 7 defaulters were between 21 and 25 years old, the age range accounting for 20 of the 26 registered patients.

\section{Conclusions}

With increasing industrialization, the need for health services for workers also steadily increases. Tuberculosis control could be a logical beginning since young workers are particularly vulnerable to this disease and on a national level, tuberculosis control is of high priority.

Several problems were identified in this pilot project, From the response it seems that services which were made available and accessible to the workers were not neces- sarily acceptable. Only $50 \%$ of the workers paticipated in the initial screening examination and only $25 \%$ of those identified as tuberculosis suspects had followup examinations. Fewer workers complied with the treatment regime. The high degree of mobility among these workers was a contributing factor. Lack of patient compliance contributed to the small number of patients served. Fear of losing their jobs may have been a factor.

This project made clear that services are needed. Broad planning programs for health education and means for communication between health services for followup of patients who move from one place of employment to another or from one city to another are health care issues which must be addressed at the national level. 